\title{
LIEMENS STABILIZAVIMO IR OTAGO PRATIMŲ PROGRAMŲ POVEIKIO SENYVO AMŽIAUS ASMENŲ FIZINEI FUNKCIJAI IR GRIUVIMO RIZIKAI PALYGINIMAS
}

\author{
Eglẻ Akelaitytė, Marija Tamulaitienė \\ Vilniaus universiteto Medicinos fakulteto Sveikatos mokslu institutas
}

Raktažodžiai: senyvas amžius, fizinès funkcijos, griuvimų rizika, liemens stabilizavimo pratimai, Otago pratimų programa.

\section{Santrauka}

Senyvo amžiaus žmonių griuvimas yra susilpnejjusios fizinès funkcijos pasekmè. Šio tyrimo tikslas - palyginti skirtingų pratimų programų poveikị senyvo amžiaus asmenų fizinei funkcijai ir griuvimo rizikai. Tyrimo metodai. Tyrimas vyko 2018-2019 metaisviešosios įstaigos Karoliniškių poliklinikos ambulatorinès reabilitacijos skyriuje. İtraukiamų i tyrimą asmenų kognityvinè funkcija ịvertinta naudojant Monrealio kognityvini testą, fizinis aktyvumas - fizinio aktyvumo skalę senyvo amžiaus asmenims. Dviem asmenų per $65 \mathrm{~m}$. amžiaus grupèms 8 savaites buvo taikytos skirtingos fizinių pratimų programos. Otago pratimų programa palyginta su liemens stabilizavimo, galūnių raumenų stiprinimo bei dinaminès pusiausvyros lavinimo pratimų programa. Fizinių funkcijų, griuvimo rizikos ir baimès tyrimas atliktas du kartus - prieš vykdant pratimų programą ir baigus ją. Fizinès funkcijos vertintos naudojant hidraulinị rankos dinamometrą, trumpaji fizinès funkcijos testų rinkinį ir Bergo pusiausvyros skalę; griuvimo rizika - „Atsistoti ir eiti“ trukmès testą; griuvimo ir judejjimo baimé - tarptautinę griuvimų efektyvumo skalę ir klausimyną apie judejjimo baimę.

Rezultatai. Tyrime dalyvavo 50 asmenų (41 moteris ir 9 vyrai), kurių vidutinis amžius $-70,1 \pm 3,6 \mathrm{~m}$. Vidutinis visų tiriamųjų fizinio aktyvumo lygis buvo $188,8 \pm 77,2$ balu pagal PASE klausimyną. Per pastaruosius 12 ménesių bent vieną kartą pargriuvę buvo 70 proc., griuvimo baimę jautė 68 proc. tiriamųjų. Po 8 savaičiu, ir pritaikius Otago pratimų programą, ir liemens stabilizavimo programą, statistiškai reikšmingai padidejjo tiriamujų fizinis pajègumas, apatinių galūnių raumenų jèga, moterų plaštakos raumenu jèga, èjimo greitis ir pagerejo pusiausvyra. Lyginant šiuos rodiklius tarp grupių, reikšmingų skirtumų nenustatyta. Vidutine „Atsistoti ir eiti“ testo atlikimo trukmè neviršijo 14 sek., ji sumažèjo abiejose tiriamujjų grupèse, tačiau tarp grupių skirtumų nebuvo. Tyrimo pradžioje griuvimo baimè įvertinta kaip vidutine $(21,9 \pm 5,2$ balo pagal FES-I), o po 8 savaičiu abiejose grupèse ji sumažejo ir buvo ịvertinta kaip nedidelè (atitinkamai 18,9 $\pm 2,5$ ir17,9 $\pm 2,5$ balų); tarp grupių reikšmingų skirtumų nenustatyta.

Išvada. Ir pritaikius Otago pratimų programą, ir liemens stabilizavimo programą senyvo amžiaus asmenims, po aštuonių savaičių padidejo jų apatinių galūnių raumenų jèga, moterų plaštakos raumenų jèga, ejimo greitis ir pagerèjo pusiausvyra, sumažèjo griuvimo baimè ir rizika, tačiau skirtumų tarp šių programų poveikio nenustatyta.

\section{İvadas}

Viena iš aktualiausių senyvo amžiaus asmenų problemų yra griuvimas. Apie trečdalis asmenų, sulaukusių 65 ir daugiau metų, pargriūna ne mažiau kaip kartą per metus [1]. Griuvimas gali sukelti ne tik fizines, bet ir psichologines, socialines bei ekonomines pasekmes [2]. Traumos, kurias patiria senyvo amžiaus asmenys griūdami, gali nulemti savarankiškumo praradimą bei slaugos poreiki, o kartais - ir mirtinas komplikacijas [3]. Griuvimas dažnai yra susilpnëjusios fizinès funkcijos pasekmè. Gera pusiausvyra yra būtinas kasdienio gyvenimo gebejjimas, kuriam reikalinga kompleksinè sensorinès informacijos apie kūno padètį erdvejje integracija ir gebejjimas generuoti tinkamus motorinius atsakus, siekiant kontroliuoti kūno judèjimą [4]. Dèl sumažèjusio judrumo palaipsniui silpnèja raumenų jèga ir mažẻja sąnarių lankstumas, mažeja èjimo greitis, trumpejja žingsnio ilgis, o šie judejjimo ir eisenos pokyčiai didina griuvimo riziką [5].

Raumenų jègos ir pusiausvyros lavinimas gali sumažinti 
senyvo amžiaus lemiamus neuroraumeninius griuvimo rizikos veiksnius iki 50 procentu [6]. Pastaruoju metu vis labiau akcentuojama atitinkama liemens raumenų darbo svarba senyvo amžiaus asmenų pusiausvyrai. Liemens raumenų, kuriems tenka pagrindinis vaidmuo užtikrinant kūno stabilumą galūnių judesių metu, silpnumas siejamas su pusiausvyros ir judrumo sumažejimu, netgi kontroliuojant kojų raumenų silpnumą $[7,8]$. Mokslinèje literatūroje nagrinètas ịvairių fizinių pratimų programų senyvo amžiaus asmenų fizinei funkcijai ir griuvimo rizikai efektyvumas, tačiau vis dar nèra bendros tyrejų nuomonės, kokia pratimų programa yra efektyviausia. Šiame tyrime tradicinių apatinių galūnių raumenų stiprinimo bei pusiausvyros lavinimo pratimų programą (Otago pratimų programa) palyginome su liemens stabilizavimo, galūniu raumenų stiprinimo bei dinaminès pusiausvyros lavinimo pratimų programa.

Tyrimo tikslas - palyginti skirtingų pratimų programų poveikị senyvo amžiaus asmenų fizinei funkcijai ir griuvimo rizikai.

\section{Tyrimo metodai}

Tyrimas vyko viešosios įstaigos Karoliniškių poliklinikos ambulatorinès reabilitacijos skyriuje nuo $2018 \mathrm{~m}$. lapkričio iki 2019 m. kovo mènesio. Dalyvauti tyrime buvo pasiūlyta 65-rių metų ir vyresniems savarankiškai judantiems moterims ir vyrams, kuriems buvo paskirta kineziterapija. Sutikę dalyvauti tyrime asmenys buvo apklausti registruojant socialinius ir demografinius duomenis, jų pažinimo funkcija ịvertinta naudojant Monrealio kognityvinị testą (MoCA) [9]. Neįtraukimo ị tyrimą kriterijai: MoCA testo ịvertis mažesnis kaip 20 balų; galūnių paralyžius, parezé, amputacijos; psichikos, regos ir klausos sutrikimai, trukdantys gauti ar suprasti pateiktą informaciją; ūminiai sveikatos sutrikimai, kurie yra kontraindikacija taikyti kineziterapiją; nepasirašyta informuoto asmens sutikimo forma.

Pirmojo tyrimo metu (I tyrimas) fizinis įtrauktų i tyrimą asmenu aktyvumas buvo vertinamas pagal Fizinio aktyvumo skalę (PASE), skirtą senyvo amžiaus asmenims [10]. Fizinè funkcija buvo tiriama naudojant Trumpaji fizinès funkcijos testų rinkini (SPPB), kuriuo ịvertinti trys rodikliai: kojų raumenų jèga - penkių atsistojimų nuo kedès testu, pusiausvyra - pagal gebejjimą išlaikyti pusiausvyrą trijose vis sudètingesnèse padètyse (mažèjant pėdų atramos plotui), ir eisena - keturių metrų èjimo testu [7]. Statinè ir dinaminè pusiausvyra buvo vertinama pagal Bergo pusiausvyros skalę (BBS) [11]. Dominuojančios rankos plaštakos raumenų jèga buvo tris kartus matuojama hidrauliniu rankos dinamometru, analizei naudojant didžiausią rezultatą. Griuvimo rizika buvo vertinama naudojant „Atsistoti ir eiti“ trukmès (Timed Up \& Go TUG) testą [12]. Jei šis testas atliekamas daugiau kaip per 14 sek., senyvo amžiaus asmenims tai vertinama kaip padidejusi griuvimo rizika. Griuvimo baimei vertinti naudota Tarptautinè griuvimų efektyvumo skalè (FES-I). Bendra skalès balų suma nuo 16 iki 22 vertinama kaip nedidelè griuvimo baimè, o nuo 23 iki 64 - didelè [13]. Judèjimo baimei ịvertinti buvo naudojamas TAMPA klausimynas [14].

Tiriamieji atsitiktinès atrankos būdu buvo suskirstyti i dvi grupes. Pirmai tiriamajai grupei (1 grupè) buvo taikyta tradicinių apatinių galūnių raumenų stiprinimo stovint ir sedint bei statinių ir dinaminių pusiausvyros ir koordinacijos lavinimo pratimų programa, sudaryta pagal Otago pratimų programą [15], panaudojant šias priemones: kėdę, lazdą ir svarelius. Antrai tiriamujų grupei (2 grupè) buvo taikyta liemens stabilizavimo, apatinių galūnių raumenų stiprinimo gulint bei dinaminès pusiausvyros ir koordinacijos lavinimo pratimų programa [16,17]; buvo naudojamos šios priemonès: kèdè, lazda bei mažas ir didelis kamuolys. Apšilimo ir atvėsimo (po $10 \mathrm{~min}$.) metu abiejose grupèse taikyti vienodi kvépavimo ir tempimo pratimai. Abiejų pratimų programų pagrindinė dalis truko 20 minučių. Pratimų intensyvumas buvo mažas arba vidutinis. Kineziterapijos užsiėmimai vyko 8 savaites, 2 kartus per savaitę. Baigusiems pratimų programą asmenims pakartotinai (II tyrimas) buvo įvertinta pusiausvyra, raumenų jèga, ejimo greitis, judejjimo baimé, griuvimo baimè ir rizika.

Statistinè tyrimo duomenų analizė atlikta naudojant Microsoft Office Excel 2010 ir SPSS programas. Apskaičiuotas aritmetinis vidurkis, standartinis nuokrypis (SN), didžiausia ir mažiausia kintamojo reikšmė. Dviejų nepriklausomų imčių vidurkių palyginimui buvo naudojami Student (t) kriterijus arba Mann-Whitney U testas, o dviejų priklausomų imčių -Student (t) kriterijus priklausomiems kintamiesiems arba Wilcoxon testas. Lyginant rezultatus skirtumas laikomas statistiškai reikšmingu, kai paklaidos tikimybès p reikšmė mažesnè už 0,05 .

\section{Tyrimo rezultatai ir jų aptarimas}

Dalyvauti tyrime buvo pasiūlyta 97 senyvo amžiaus asmenims. Vykdyti pratimų programą savanoriškai sutiko 61 asmuo, iš jų 3 neatitiko ịtraukimo ị tyrimą kriterijų, 4 pakeite savo nuomonę ir atsisakẻ dalyvauti dar neprasidèjus ir 4 - prasidejus tyrimui. Fizinių pratimų programą vykdè ir pabaigè (lanke் $\geq 80$ proc. užsiëmimų) 50 asmenų -41 moteris ir 9 vyrai. Jauniausias tiriamasis buvo 65 , o vyriausias -83 metų. I pirmą tiriamają grupę pateko 21 moteris ir 4 vyrai, o ị antrą - 20 moterų ir 5 vyrai. Bendra tirtu asmenų charakteristika pateikta 1 lentelejje.

Daugiau kaip du trečdaliai tiriamujų (70 proc.) per pastaruosius 12 menesių buvo pargriuvę, dauguma iš jų - vieną kartą. Vidutinis visų tiriamujų fizinio aktyvumo lygis pagal 
PASE klausimyną vertinamas kaip pakankamas. Tiriamų asmenų grupès pagal bendrus tiriamujų charakteristikos duomenis buvo vienodos. Statistiškai reikšmingų skirtumų tarp grupių nenustatyta ir išanalizavus I tyrimo metu (prieš pradedant vykdyti fizinių pratimų programą) gautus duomenis, apibūdinančius tiriamųjų fizines funkcijas, griuvimo riziką ir griuvimo bei judejjimo baimę. Šių rodiklių vertinimo rezultatų vidurkių palyginimas tarp pirmojo ir

1 lentelè. Bendra tirtu asmenu charakteristika

$S N$-standartinis nuokrypis; $p$-paklaidos tikimybès reikšmé, lyginant 1 ir 2 grupes, *- Chi kvadrato kriterijus;

** - Mann-Whitney testo kriterijus nepriklausomoms imtims; ${ }^{* * *}$ - Student (t) kriterijus nepriklausomoms imtims; PASE - fizinio aktyvumo skalè senyvo amžiaus asmenims.

\begin{tabular}{|c|c|c|c|c|}
\hline \multirow{2}{*}{ Rodiklis } & \multicolumn{3}{|c|}{ Tirti asmenys } & \multirow{2}{*}{$\mathbf{p}$} \\
\hline & visi & 1 grupe & 2 grupe & \\
\hline \multirow{3}{*}{$\begin{array}{l}\text { Tiriamujų skaičius (proc.) } \\
\text { iš jų: moterys } \\
\text { vyrai }\end{array}$} & $50(100)$ & $25(50)$ & $25(50)$ & \multirow{3}{*}{$\begin{array}{c}- \\
0,713 *\end{array}$} \\
\hline & $41(82)$ & $21(84)$ & $20(80)$ & \\
\hline & $9(18)$ & $4(16)$ & $5(20)$ & \\
\hline $\begin{array}{l}\text { Amžius metais, } \\
\text { vidurkis } \pm \text { SN }\end{array}$ & $\begin{array}{c}70,12 \pm \\
3,65\end{array}$ & $\begin{array}{l}70,16 \\
\pm 3\end{array}$ & $\begin{array}{c}70,08 \pm \\
4,26\end{array}$ & $0,532 * *$ \\
\hline $\begin{array}{l}\text { Griuvimų per } 12 \text { mèn. } \\
\text { skaičius, vidurkis } \pm \text { SN }\end{array}$ & $\begin{array}{c}1,06 \pm \\
0,91\end{array}$ & $\begin{array}{c}1,08 \pm \\
0,91 \\
\end{array}$ & $\begin{array}{c}1,04 \pm \\
0,94 \\
\end{array}$ & $0,853 * *$ \\
\hline \multirow{5}{*}{$\begin{array}{l}\text { Griuvimų skaičius } \\
\text { (proc.): } \\
\text { negriuvo } \\
\text { pargriuvo } 1 \text { kartą } \\
\text { pargriuvo } 2 \text { kartus } \\
\text { pargriuvo } 3 \text { kartus }\end{array}$} & & & & \multirow{5}{*}{$0,99 *$} \\
\hline & $15(30)$ & $7(28)$ & $8(32)$ & \\
\hline & $21(42)$ & $11(44)$ & $10(40)$ & \\
\hline & $10(20)$ & $5(20)$ & $5(20)$ & \\
\hline & $4(8)$ & $2(8)$ & $2(8)$ & \\
\hline $\begin{array}{l}\text { Fizinis aktyvumas balais } \\
\text { pagal PASE,vidurkis } \pm \text { SN }\end{array}$ & $\begin{array}{c}188,8 \pm \\
77,2\end{array}$ & $\begin{array}{c}189,3 \pm \\
89,7\end{array}$ & $\begin{array}{c}188,2 \pm \\
64,2\end{array}$ & $0,961 * * *$ \\
\hline
\end{tabular}

antrojo tyrimo abiejose tirtose grupèse pateiktas 2 lentelèje.

Ivykdžius fizinių pratimų programą, tiriamujų funkcinis pajègumas reikšmingai padidejo abiejose grupèse, tačiau palyginus II tyrimo rezultatus tarp grupių, statistiškai reikšmingo skirtumo nenustatyta. Ėjimo greitis padidejo ir pusiausvyra pagerejjo tiek įvykdžius pirmą, tiek antrą pratimų programas, tačiau tarp grupių II tyrimo duomenys statistiskai reikšmingai nesiskyrè. I̦vykdžius abi pratimų programas, reikšmingai padidejjo apatinių galūnių raumenų jèga. Baigus pratimų programą, 32 proc. pirmosios ir 52 proc. antrosios grupès tiriamujų 5 kartų atsistojimo testą atliko greičiau nei per 11,19 sek. ir buvo įvertinti didžiausiu galimu (4) balu. Tarp skirtingų grupių II tyrimo rezultatų reikšmingo skirtumo nenustatyta. Vyrų ir moterų plaštakos raumenų jègos matavimo hidrauliniu rankos dinamometru rezultatai buvo lyginami atskirai. Moterų plaštakos raumenų jèga reikšmingai padidejo įvykdžius tiek pirmą, tiek antrą pratimų programą. Palyginus vyrų I ir II ištyrimo rezultatus, reikšmingų pokyčių nekonstatuota nei pirmoje, nei antroje grupeje. Tarp tiriamujų grupių, atskirai įvertinus moterų ir vyrų rankų raumenų jègą, reikšmingų skirtumų nenustatyta.

Tyrimo pradžioje tik vienas iš tiriamųų, atlikdamas TUG testą, užtruko ilgiau kaip 14 sek., tai vertinama kaip didelè griuvimo rizika. Kitiems tiriamiesiems padidejusi griuvimų rizika nenustatyta. İvykdžius abi pratimų programas, TUG testo atlikimo trukmè vidutiniškai sumažejo (2 lentelè), tačiau palyginus II tyrimo šio testo rezultatų vidurkius, reikšmingų skirtumų tarp grupių nenustatyta. Prieš pradėdami vykdyti fizinių pratimų programą 34 tiriamieji (68 proc.) nurodè bijantys pargriūti, o vertinant pagal FES-I klausi-

2 lentelè. Tirtų rodiklių prieš ir po pratimų programos palyginimas dviejose senyvo amžiaus asmenų grupėse. SN - standartinis nuokrypis; $n$ - tiriamuju skaičius; $p$ - paklaidos tikimybès reikšme lyginant I ir II tyrimu rezultatus; SPPB - Trumpasis fizinès funkcijos testu rinkinys; BBS - Bergo pusiausvyros skale; TUG - „, Atsistoti ir eiti“ trukmès testas; FES-I - Tarptautine griuvimu efektyvumo skalé; TAMPA - klausimynas apie judëjimo baimę.

\begin{tabular}{|c|c|c|c|c|c|c|}
\hline \multirow{3}{*}{ Rodiklis } & \multicolumn{3}{|c|}{1 grupè } & \multicolumn{3}{|c|}{2 grupè } \\
\hline & I tyrimas & II tyrimas & \multirow[t]{2}{*}{$\mathrm{p}$} & I tyrimas & \begin{tabular}{c|c} 
II tyri- \\
mas
\end{tabular} & \multirow[t]{2}{*}{$\mathrm{p}$} \\
\hline & \multicolumn{2}{|c|}{ vidurkis \pm SN } & & \multicolumn{2}{|c|}{ vidurkis \pm SN } & \\
\hline Funkcinis pajėgumas (SPPB, balai): & $9,48 \pm 1,05$ & $11,16 \pm 0,69$ & $<0,01$ & $9,16 \pm 1,38$ & $11,36 \pm 0,76$ & $<0,01$ \\
\hline Pusiausvyros testų suma (balai) & $3,76 \pm 0,52$ & $4,0 \pm 0,0$ & 0,034 & $3,6 \pm 0,58$ & $3,96 \pm 0,2$ & 0,003 \\
\hline $4 \mathrm{~m}$ èjimo testas (balai) & $3,84 \pm 0,37$ & $4,0 \pm 0,0$ & 0,046 & $3,76 \pm 0,52$ & $4,0 \pm 0,0$ & 0,034 \\
\hline $5 \mathrm{k}$. atsistojimo testas (balai) & $1,88 \pm 0,78$ & $3,16 \pm 0,69$ & $<0,01$ & $1,8 \pm 0,76$ & $3,4 \pm 0,71$ & $<0,01$ \\
\hline Pusiausvyra (BBS, balai) & $52,44 \pm 1,73$ & $55,36 \pm 0,76$ & $<0,01$ & $51,92 \pm 2,66$ & $55,12 \pm 1,2$ & $<0,01$ \\
\hline Plaštakos raumenų jėga $(\mathrm{kg})$ & & & & & & \\
\hline $\begin{array}{l}\text { moterų } \\
\text { vyrų }\end{array}$ & $\begin{array}{c}21, / 0 \pm 3,59 \\
39,5 \pm 1,0\end{array}$ & $\begin{array}{l}22,24 \pm 3,59 \\
39,75 \pm 1,26\end{array}$ & $\begin{array}{l}0,024 \\
0,317\end{array}$ & $\begin{array}{c}22,50 \pm 5,65 \\
39 \pm 5,48\end{array}$ & $\begin{array}{c}23,25 \pm 5,0 / \\
39,6 \pm 6,11\end{array}$ & $\begin{array}{l}0,003 \\
0,208\end{array}$ \\
\hline Griuvimo rizika (TUG testas, sek.) & $9,32 \pm 1,51$ & $7,02 \pm 1,17$ & $<0,01$ & $9,72 \pm 1,79$ & $6,97 \pm 1,17$ & $<0,01$ \\
\hline Griuvimo baimė (FES-I, balai) & $23,04 \pm 5,52$ & $18,92 \pm 2,55$ & $<0,01$ & $20,8 \pm 4,8$ & $17,92 \pm 2,48$ & $<0,01$ \\
\hline $\begin{array}{l}\text { Judejjimo baimè (TAMPA, balai), } \\
\mathrm{n}=12\end{array}$ & $38,67 \pm 5,01$ & $36,17 \pm 4,88$ & 0,022 & $40,33 \pm 4,72$ & $37,17 \pm 3,06$ & 0,008 \\
\hline
\end{tabular}


myną tiriamujų griuvimo baimė buvo įvertinta kaip vidutinè (daugiau nei 20 balų). Po 8 savaičių trukmès fizinių pratimų visų tiriamujų griuvimo baimè reikšmingai sumažèjo, tačiau tarp grupių reikšmingo skirtumo nenustatyta. II tyrimo metu vidutinis visų tiriamujų balas pagal FES-I buvo mažesnis nei 20 balų, todèl griuvimo baimè buvo įvertinta kaip maža. Palyginus griuvusių ir negriuvusių asmenų griuvimo rizikos ir griuvimo baimès ịvertinimo rezultatus, statistiškai reikšmingų skirtumų nerasta. Tyrimo pradžioje judèjimo ar skausmo baimę jautè 12 tiriamujų, po 6 tiriamuosius abiejose grupèse. Judejjimo baimè reikšmingai sumažèjo abiejose grupèse, bet tarp grupių statistiškai reikšmingo skirtumo nenustatyta.

Šiuo tyrimu siekėme išsiaiškinti, kuri fizinių pratimų programa yra pranašesnè, siekiant pagerinti senyvo amžiaus asmenų fizines funkcijas ir sumažinti griuvimo riziką bei baimę. Mūsų tyrimo rezultatai parodè, kad ịvykdžius dvi skirtingas fizinių pratimų programas, padidèjo senyvo amžiaus asmenų apatinių galūnių raumenų jèga ir ejjimo greitis, pagerèjo pusiausvyra, sumažejo griuvimo rizika ir griuvimo bei judejjimo baimè, tačiau nenustatème kurios nors iš tirtų programų pranašumo.

Mūsų tyrimo rezultatai yra panašūs ị C. Arnoldo ir bendraautorių [18] tyrimo rezultatus. Šie autoriai lygino, kaip 23 senyvo amžiaus asmenys, kurie turejjo bent vieną griuvimo rizikos veiksnị, atlieka stotis-sėstis testą įvykdę 9 savaičių liemens raumenų stabilizavimo pratimų, skirtų pusiausvyros ir posturalinės kontrolès gerinimui, programą ir standartinių pusiausvyros pratimų programą. Autoriai išvadose teigia, kad liemens raumenų stabilizavimo lavinimas, palyginti su standartiniu pusiausvyros lavinimu, nedavė reikšmingų stotis-sèstis testo pagerèjimo rezultatų. Mūsų tyrime taikytos pratimų programos truko 8 savaites. Atlikus mokslinius tyrimus, kuriuose intervencijos buvo ilgesnès trukmès, buvo gauti geresni rezultatai. F. Hassanas su bendraautoriais [5] vertino liemens rotacijos 12 savaičiu trukmès pratimų programos efektyvumą senyvo amžiaus asmenų pusiausvyrai ir nustate, kad papildomų liemens raumenų stiprinimo pratimų poveikis senyvo amžiaus asmenų pusiausvyrai yra efektyvus.

Nustatyta, kad ne tik apie pusè griuvusiujų, bet ir didelè dalis niekada negriuvusių senyvo amžiaus asmenų (dažniau moterys), kurių objektyviai ịvertinta griuvimo rizika santykinai maža, bijo griūti [19]. Mūsų tyrimo duomenimis, griuvimo baimę jautė net 68 proc. tiriamụjų. Tokį rezultatą galèjo nulemti tai, kad 82 proc. tiriamujų buvo moterys. Fiziniai pratimai, kurie didina raumenų jègą, gerina pusiausvyros kontrolę ir eisenos kokybę, padeda sumažinti ir griuvimo baimę, kadangi jos atsiradimą lemia sumažejęs fizinis ir funkcinis pajègumas, pusiausvyros ir eisenos sutrikimai [20]. Nepaisant įrodytos liemens raumenų svarbos kūno stabilumui, mūsų atliktas tyrimas neatskleidè, kad siekiant pagerinti senyvo amžiaus asmenų fizinę funkciją ir sumažinti griuvimo riziką, liemens stabilizavimo pratimų programa yra pranašesnè už Otago pratimų programą. Šio tyrimo galimas trūkumas - mažas tiriamujų skaičius, santykinai jaunas amžius. Manytume, kad vykdant tolesnius šios krypties tyrimus, derètų itraukti didesnị skaičių vyresnių kaip 75 metų asmenų, kurių griuvimo rizika ir baimè būtų didesnè negu vidutinio lygio, ilgiau taikyti fizinius pratimus.

\section{Išvada}

Tiek pritaikius Otago pratimų programą, tiek liemens stabilizavimo programą senyvo amžiaus asmenims, po aštuonių savaičių padidejo jų apatinių galūnių raumenų jẻga, moterų plaštakos raumenų jèga, ejjimo greitis ir pagerejo pusiausvyra, sumažejo griuvimo baimè ir rizika, tačiau skirtumų tarp šių programų poveikio nenustatyta.

\section{Literatūra}

1. Padala KP, Padala PR, Lensing SY, Dennis RA, Bopp MM, et al. Efficacy of Wii-Fit on static and dynamic balance in community dwelling older veterans. Journal of Aging Research 2017; 1-9. https://doi.org/10.1155/2017/4653635

2. Piščalkienė V., Januškevičiūtė R., Dovydaitis J. Pagyvenusių ir senų žmonių griuvimų rizikos veiksniai ir jų itaka griuvimams. Sveikatos mokslai, 2015; 25(5):5-12.

https://doi.org/10.5200/sm-hs.2015.081

3. Cho SI, An DH. Effects of a fall prevention exercise program on muscle strength and balance of the old-elderly. Journal Physical Therapy Science 2014;26(11):1771-1774. https://doi.org/10.1589/jpts.26.1771

4. Horak FB, Henry SM, Shumway-Cook A. Postural perturbations: new insights for treatment of balance disorders. International Journal of Physiotherapy and Research 2014; 77(5): 517-32. https://doi.org/10.1093/ptj/77.5.517

5. Hassan Ali FM, Abd-Elaziz A, Ismail SM. Efficacy of trunk rotation exercises on balance in elderly. International Journal of Therapies \& Rehabilitation Research 2016;5(5):16-22. https://doi.org/10.5455/ijtrr.000000177

6. Gillespie LD, Robertson MC, Gillespie WJ, Sherrington C, Gates S, et al. Interventions for preventing falls in older people living in the community. Cochrane Database Syst Rev 2012; 9. https://doi.org/10.1002/14651858.CD007146.pub3

7. Suri P, Kiely DK, Leveille SG, Frontera WR, Bean JF. Trunk muscle attributes are associated with balance and mobility in older adults: a pilot study. NIH Public Access 2010; 1(10): 916-924. https://doi.org/10.1016/j.pmrj.2009.09.009

8. Kim SG, Yong MS, Na SS. The effect of trunk stabilization exercises with a Swiss ball on core muscle activation in the elderly. J Phys Ther Sci 2014;26:1473-1474.

https://doi.org/10.1589/jpts.26.1473 
9. Nasreddine ZS, Phillips NA, Bedirian V, et al. The Montreal cognitive assessment, MoCA: a brief screening tool for mild cognitive impairment. J Am Geriatr Soc. 2005;53:695-699. https://doi.org/10.1111/j.1532-5415.2005.53221.x

10. Washburn RA, Smith KW, Jette AM, Janney CA. The physical activity scale for the elderly (PASE) - development and evaluation. J Clin Epidemiol 1993;46:153-162.

https://doi.org/10.1016/0895-4356(93)90053-4

11. Berg KO, Wood-Dauphinee SL, Williams JI, Maki B. Measuring balance in the elderly: validation of aninstrument. Canadian Journal of Public Health 1992;83:7-11.

12. Podsiadlo D, Richardson S. The timed "Up \& Go": a test of basic functional mobility for frail elderly persons. J Am Geriatr Soc 1991;39(2):142-148.

https://doi.org/10.1111/j.1532-5415.1991.tb01616.x

13. Delbaere K, Close JC, Mikolaizak AS, Sachdev PS, Brodaty $\mathrm{H}$, Lord SR. The falls efficacy scale international (FES-I). A comprehensive longitudinal validation study. Age Ageing 2010; 39: 210-216.

https://doi.org/10.1093/ageing/afp225

14. Kori SH, Miller RP, Todd DD. Kinesiophobia: a new view of chronic pain behavior. Pain Manag 1990;3:35-43.

15. Shubert TE, Smith ML, Ory MG, Jiang L. Disseminating the Otago exercise program in the United States: perceived and actual physical performance improvements from participants. Journal of Applied Gerontology 2018; 37(1): 79-98.

https://doi.org/10.1177/0733464816675422

16. Donath L, Kurz E, Roth R, Zahner L, Faude O. Leg and trunk muscle coordination and postural sway during increasingly difficult standing balance tasks in young and older adults. Maturitas 2016;91:60-68.

https://doi.org/10.1016/j.maturitas.2016.05.010

17. Arnold C, Lanovaz J, Oates A, Craven B, Butcher S. The effect of adding core stability training to a standard balance exercise program on sit to stand performance in older adults: a pilot study. J Aging Phys Act 2015;23(1):95-102.

https://doi.org/10.1123/JAPA.2013-0115

18. Arnold C, Lanovaz J, Oates A, Craven B, Butcher S. The effect of adding core stability training to a standard balance exercise program on sit to stand performance in older adults: a pilot study. J Aging Phys Act 2015;23(1):95-102.

https://doi.org/10.1123/JAPA.2013-0115

19. Wetherell JL, Johnson K, Chang D, Ward SR, Bower ES et al. Activity, balance, learning, and exposure (ABLE): a new intervention for fear of falling. International Journal of Geriatric Psychiatry 2016;31(7):2-9.

https://doi.org/10.1002/gps.4393

20. Mendes da Costa E, Pepersack T, Godin I, Bantuelle M, Petit B, Leveque A. Fear of falling and associated activity restriction in older people. results of a cross-sectional study conducted in a Belgian town. Arch Public Health. 2012; 70(1):1-7.

https://doi.org/10.1186/0778-7367-70-1

\section{COMPARING OF THE EFFECT OF OTAGO AND CORE STABILITY EXERCISE PROGRAMS ON THE PHYSICAL FUNCTION AND RISK OF FALLS IN ELDERLY PEOPLE}

\section{E. Akelaitytè, M. Tamulaitienè}

Keywords: the elderly, physical function, risk of falls, core stability exercises, Otago excersise program.

Summary

The falls of elderly people are the result of weakened physical function. The aim of this study is to compare the effect of different exercise programs on physical function and risk of falls in the elderly.

Methods of research. The research was performed at the Rehabilitation Department of PI Karoliniškių Outpatient Clinic in 2018-2019. The cognitive function of the surveyed persons was assessed by using the Montreal Cognitive test, the physical activity - by Physical Activity Scale for the Elederly. Different programs of physical exercises were applied to two groups of the elderly aged over 65 for 8 weeks. The Otago exercise program was compared to the program of exercises for core stability, lower extremity muscle strengthening and dynamic balance training. The analysis of physical functions, risk and fear of falling was performed twice - before the physical exercise program and after it. Physical functions were assessed by using a hydraulic hand dynamometer, the Short Physical Performance Battery (SPPB) and Berg balance scale; risk of falls - by the Timed Up and Go (TUG) test; fear of falling and moving - by the Falls Efficacy Scale - International (FES-I) and the Tampa Scale for Kinesiophobia respectively.

Results. The study included 50 persons ( 41 women and 9 men) the average age of whom was $70.1 \pm 3.6$ years. The average level of physical activity of the surveyed was $188.8 \pm 77.2$ scores according to PASE. Within the recent 12 months 70 percent of the surveyed suffered at least one fall and 68 percent felt fear of falling. After 8 weeks of exercising both under the Otago and core stability programs statistically important improvement was observed in general physical function of the surveyed, lower extremity muscle strenghth, handgrip strength in women, walking speed and balance. By comparing the indices between the groups no significant differences were found out. The duration of TUG test performance did not exceed 14 sec., it decreased in both groups of the surveyed, however, there were no differences between the groups. At the beginning of the study fear of falling was assessed as average (21.9 \pm 5.2 scores according to FES-I) and after 8 weeks it decreased in both groups and was assessed as not great (18.9 \pm 2.5 and $17.9 \pm 2.5$ scores respectively); no significant differences between the groups were observed.

Conclusion. Having applied both the Otago exercises program and core stability program to the elderly for 8 weeks, there was improvement in their lower extremity muscle strenghth, handgrip strength in women, walking speed and balance, decrease in fear and risk of falling. However, differences in the effect between these programs were not observed.

Correspondence to: egle.akelaityte@gmail.com

Gauta 2020-01-23 